\title{
PENGARUH PERHATIAN ORANG TUA TERHADAP HASIL BELAJAR MATEMATIKA SISWA KELAS IV SDN SEKECAMATAN KUTOWINANGUN TAHUN AJARAN 2020/2021
}

\author{
Cita Suci Afira ${ }^{1}$, Muhamad Chamdani ${ }^{2}$, \& Kartika Chrysti Suryandari ${ }^{3}$ \\ Universitas Sebelas Maret \\ citasuciafira23@gmail.com
}

\section{Article History}

accepted 30/8/2021

\begin{abstract}
Parental attention is one of the factors that influence the high and low learning outcomes of mathematics. This study aimed to determine the effect of intentional parental attention on mathematics learning outcomes and the effect of spontaneous parental attention on mathematics learning outcomes for fourth grade elementary school students in Kutowinangun District for the academic year 2020/2021. This research is a quantitative research with survey method. In data analysis, the researcher used the SPSS application to analyze the regression. The results showed that the effect of intentional parental attention on mathematics learning outcomes was $55.5 \%$ (sig. $0.00<0.05)$ and the influence of spontaneous type of parental attention to mathematics learning outcomes was $31.8 \%$ (sig. $0.00<0.05$ ). The results showed that there was an influence of the type of intentional parental attention and the influence of the type of spontaneous parental attention on the mathematics learning outcomes of fourth grade elementary school students in Kutowinangun District, where the better parental attention is given, the higher the mathematics learning outcomes will also be.
\end{abstract}

Keywords: parental attention, mathematics learning outcomes

\section{Abstrak}

Perhatian orang tua merupakan salah satu faktor yang memengaruhi tinggi rendahnya hasil belajar matematika. Penelitian ini bertujuan untuk mengetahui adanya pengaruh jenis perhatian orang tua disengaja terhadap hasil belajar matematika dan pengaruh jenis perhatian orang tua spontan terhadap hasil belajar matematika siswa kelas IV SDN se-Kecamatan Kutowinangun tahun ajaran 2020/2021. Penelitian ini merupakan penelitian kuantitatif dengan metode survei. Pada analisis data, peneliti menggunakan aplikasi SPSS untuk menganalisis regresi. Hasil penelitian menunjukkan bahwa pengaruh jenis perhatian orang tua disengaja terhadap hasil belajar matematika sebesar $55,5 \%$ (sig. $0,00<0,05$ ) dan pengaruh jenis perhatian orang tua jenis spontan terhadap hasil belajar matematika sebesar $31,8 \%$ (sig. 0,00 $<0,05$ ). Hasil penelitian menunjukkan bahwa terdapat pengaruh jenis perhatian orang tua disengaja dan pengaruh jenis perhatian orang tua spontan terhadap hasil belajar matematika siswa kelas IV SDN se-Kecamatan Kutowinangun, dimana semakin baik perhatian orang tua yang diberikan, maka hasil belajar matematika juga akan semakin tinggi.

Kata Kunci: perhatian orang tua, hasil belajar matematika 


\section{PENDAHULUAN}

Perkembangan abad ke-21 ditandai dengan pemanfaatan teknologi informasi dan komunikasi dalam segala aspek kehidupan, termasuk dunia pendidikan. Pada pendidikan abad ke-21 setiap orang harus memiliki keterampilan berpikir kritis, pengetahuan dan kemampuan literasi digital serta menguasai teknologi. Di balik maraknya perbincangan mengenai abad ke-21 perlu dipersiapkan keterampilan yang harus dimikili siswa bagi seluruh jenjang pendidikan dan semua mata pelajaran, tak terkecuali matematika. Nahdi (2019) menjelaskan bahwa matematika memiliki kekuatan yang mampu diaplikasikan ke dalam beberapa aspek, termasuk teknologi.

Menurut Wahyudi (2015) matematika merupakan bahan kajian yang mempunyai objek abstrak dan dibangun berdasarkan penalaran deduktif, artinya kebenaran konsep didapatkan melalui akibat logis dari kebenaran sebelumnya. Sampai saat ini matematika masih dianggap mata pelajaran yang sulit, membosankan dan menakutkan, hal ini menyebabkan siswa merasa kurang bersemangat setiap menerima mata pelajaran matematika. Siswa cenderung bersikap pasif saat mata pelajaran matematika disampaikan oleh guru.

Hasil belajar matematika siswa yang belum maksimal dipengaruhi oleh beberapa faktor, salah satu faktor penyebabnya dari dalam diri siswa sendiri yaitu mengalami masalah dalam mempelajari matematika. Selain itu, lingkungan menjadi faktor penyebab masalah, lingkungan yang tidak mendukung siswa untuk belajar matematika secara maksimal menyebabkan masalah dalam belajar. Hasil belajar akan mengubah tingkah laku dan kemampuan yang dimiliki siswa dengan adanya pengalaman belajar yang didapatkan saat pembelajaran berlangsung. Menurut Nur (2016) hasil belajar merupakan suatu keberhasilan siswa yang diperoleh dari hasil belajarnya dan keberhasilan ini dapat dilakukan melalui pengukuran atau evaluasi. Hasil belajar menjadi sebuah penilaian dan pengukuran kegiatan pembelajaran, hal ini dapat dilakukan melalui kegiatan evaluasi. Adiani dan Kristiantari (2020) menyatakan bahwa "Learning outcomes are a process wherein there is a change in individual learners where these changes occur in the affective, cognitive, and psychomotor domains of students after learning activities". Maksudnya hasil belajar merupakan suatu proses dimana terjadi perubahan pada individu peserta didik dimana perubahan tersebut terjadi pada ranah afektif, kognitif, dan psikomotor peserta didik setelah kegiatan pembelajaran. Hasil belajar yang baik dapat dicapai apabila siswa aktif dalam mengikuti pembelajaran. Hasil belajar siswa dapat berupa perubahan aspek kognitif, afektif, dan psikomotorik.

Pengaruh keluarga yang dapat memengaruhi hasil belajar antara lain pendidikan, pola asuh, perhatian orang tua, kelekatan atau keakraban antara sesama anggota keluarga, latar belakang budaya, keadaan ekonomi keluarga, dan lain sebagainya. Faktor ini dianggap penting karena dalam sebuah keluarga perhatian orang tua memegang peranan utama untuk membentuk anak-anaknya menjadi manusia yang berakhlak dan cerdas. Theresya, Latifah \& Hernawati (2018) menyatakan bahwa "Based on the research results, it can be concluded that to be able to improve learning outcomes of children, parents educate their children by giving direction, attention and give the child responsibility alone". Berdasarkan hasil analisis data dapat diketahui bahwa untuk dapat meningkatkan hasil belajar anak, orang tua mendidik anaknya dengan dengan memberikan arahan, perhatian dan memberikan anak tanggung jawab sendiri.

Kurangnya perhatian orang tua terhadap hasil belajar siswa merupakan tantangan terhadap dunia pendidikan. Upaya peningkatan hasil belajar harus dilakukan. Hal ini selalu berkaitan dalam profesi keguruan dan dunia kependidikan. Sebagian dari orang tua beranggapan bahwa pendidikan merupakan tugas guru di sekolah sehingga sudah cukup hanya menyekolahkan saja, maka tanggung jawab mereka atas pendidikan anaknya telah terpenuhi. Mereka beranggapan bahwa tidak perlu lagi memperhatikan belajar anaknya di rumah karena sudah cukup belajar di sekolah. Selain itu, 
pengetahuan orang tua terhadap pentingnya pendidikan bagi anak masih rendah serta mereka juga kurang menyadari pentingnya perhatian orang tua terhadap hasil belajar siswa. Perhatian orang tua dalam pendidikan diartikan sebagai usaha dan dorongan orang tua kepada anaknya dalam kegiatan belajar, baik di rumah maupun di sekolah (Kurniawan \& Dhoriva, 2014). Orang tua mempunyai peranan penting dalam tugas dan tanggung jawabnya yang besar terhadap semua anggota keluarga yaitu lebih bersifat pembentukan watak dan budi pekerti, latihan keterampilan dan ketentuan rumah tangga, dan sejenisnya. Rini (2015) menyatakan bahwa bentuk perhatian orang tua meliputi pemberian bimbingan belajar, memberikan nasihat, memberikan motivasi dan penghargaan, memenuhi kebutuhan anaknya, pengawasan terhadap anaknya.

Tujuan penelitian ini yaitu (1) Mengetahui adanya pengaruh jenis perhatian orang tua disengaja terhadap hasil belajar matematika; (2) Mengetahui adanya pengaruh jenis perhatian orang tua spontan terhadap hasil belajar matematika siswa kelas IV SDN seKecamatan Kutowinangun tahun ajaran 2020/2021.

\section{METODE}

Penelitian ini merupakan penelitian kuantitatif dengan metode penelitian survei. Menurut Priyatno (2012) metode penelitian survei adalah metode penelitian kuantitatif yang digunakan untuk memperoleh data yang terjadi pada masa lampau atau saat ini, teknik pengumpulan data menggunakan wawancara atau kuesioner dan hasil penelitian cenderung untuk digeneralisasikan. Populasi penelitian ini yaitu siswa kelas IV SDN seKecamatan Kutowinangun sejumlah 633 siswa dengan sampel sebanyak 257 siswa di dua belas SDN di Kecamatan Kutowinangun. Teknik pengambilan sampel yang digunakan yaitu teknik probability sampling jenis cluster random sampling.

Teknik pengumpulan data yang digunakan dalam penelitian ini berupa angket dan tes. Angket digunakan untuk mengumpulkan data perhatian orang tua dan tes digunakan untuk mengumpulkan data hasil belajar matematika. Instrumen penelitian ini yaitu angket perhatian orang tua yang terdiri dari jenis perhatian disengaja dengan indikator pemberian bimbingan belajar, memberikan nasihat, memberikan motivasi dan penghargaan, dan jenis perhatian spontan dengan indikator memenuhi kebutuhan anaknya dan pengawasan terhadap anaknya. Selanjutnya, tes matematika terdiri dari materi kelas IV SD semester gasal tahun ajaran 2020/2021.

Uji prasyarat data penelitian ini yaitu uji normalitas data dan uji linieritas data. Setelah data memenuhi prasyarat yang ditentukan, data akan dianalisis menggunakan analisis regresi, analisis korelasi, dan sumbangan efektif.

\section{HASIL DAN PEMBAHASAN}

Penelitian ini dilakukan dengan memberikan angket perhatian orang tua dan soal tes hasil belajar matematika siswa kelas IV SD yang menjadi sampel penelitian. Uji prasyarat data pada penelitian ini telah terpenuhi yaitu data berdistribusi normal dan data linier.

Berdasarkan uji normalitas data, diperoleh nilai signifikansi untuk data variabel perhatian orang tua yaitu 0,136 dan nilai sig. variabel hasil belajar matematika 0,438 , sehingga dapat diketahui bahwa signifikansi $>0,05$. Oleh karena itu, dapat disimpulkan bahwa terima $\mathrm{Ho}$ atau variabel perhatian orang tua dan hasil belajar matematika berasal dari populasi yang berdistribusi normal.

Berdasarkan uji linieritas yang telah dilakukan, dapat diketahui bahwa Sig. Deviation from Linearity yaitu 0,267, sehingga dapat diketahui bahwa signifikansi 0,267 >0,05. Oleh karena itu, dapat disimpulkan bahwa Ho diterima atau terdapat hubungan linier antara hasil belajar matematika dan perhatian orang tua. 
Setelah uji prasyarat analisis data telah terpenuhi, selanjutnya dilakukan analisis data uji hipotesis.

Tabel 1. Hasil Uji Analisis Perhatian Orang Tua terhadap Hasil Belajar Matematika

\begin{tabular}{llcccc}
\hline \multicolumn{1}{c}{ Jenis } & $\mathrm{R}$ & $\mathrm{R}$ Square & SE (\%) & $\mathrm{F}$ & Sig. \\
\hline Derhatian & $.745^{\mathrm{a}}$ & .555 & 55,5 & 318.301 & $.000^{\mathrm{b}}$ \\
Sisengaja & $.564^{\mathrm{a}}$ & .318 & 31,8 & 118.705 & $.000^{\mathrm{b}}$ \\
\hline
\end{tabular}

Hipotesis pertama pada penelitian ini $\mathrm{Ho}_{1}$ tidak terdapat pengaruh positif antara jenis perhatian disengaja dengan hasil belajar matematika siswa kelas IV SDN se-Kecamatan Kutowinangun tahun ajaran 2020/2021. Berdasarkan hasil nilai $F$ hitung jenis perhatian disengaja $=318,301$ dengan tingkat signifikasi sebesar $0,000<0,05$ sehingga $\mathrm{Ho}_{1}$ ditolak. Berdasarkan uji regresi yang telah dilakukan, dapat diketahui bahwa besarnya nilai korelasi/ hubungan $(R)$ jenis perhatian disengaja dengan hasil belajar matematika sebesar 0,745 dan dari tabel tersebut diketahui koefisien determinasi ( $R$ Square) sebesar 0,555 , yang artinya pengaruh jenis perhatian orang tua disengaja terhadap hasil belajar matematika sebesar $55,5 \%$.

Berdasarkan penelitian dan perhitungan yang telah dilakukan, dapat diketahui bahwa jenis perhatian disengaja berpengaruh positif terhadap hasil belajar matematika dimana semakin baik perhatian orang tua jenis disengaja yang diberikan oleh orang tua, maka akan semakin tinggi pula hasil belajar matematika siswa. Hal tersebut diperkuat dengan pendapat Safitri dan Nurhayati (2018) yang menyatakan bahwa perhatian orang tua memberikan dampak yang baik bagi anak seperti meningkatkan semangat dan motivasi belajar bagi anak. Perhatian dan bimbingan orang tua di rumah akan memengaruhi kesiapan belajar siswa, baik belajar di rumah maupun di sekolah.

Hipotesis kedua pada penelitian $\mathrm{Ho}_{2}$ tidak terdapat pengaruh positif antara jenis perhatian spontan dengan hasil belajar matematika siswa kelas IV SDN se-Kecamatan Kutowinangun tahun ajaran 2020/2021. dan nilai $F$ hitung jenis perhatian spontan $=$ 118,265 dengan tingkat signifikasi sebesar $0,000<0,05$ sehingga $\mathrm{Ho}_{2}$ ditolak. Besarnya nilai korelasi/ hubungan $(R)$ jenis perhatian spontan dengan hasil belajar matematika juga dapat dilihat dari tabel, yang menyatakan nilai $R$ sebesar 0,564 dan diketahui koefisien determinasi (R Square) sebesar 0,318, yang artinya pengaruh jenis perhatian orang tua jenis spontan terhadap hasil belajar matematika sebesar 31,8 \%.

Berdasarkan penelitian dan perhitungan yang telah dilakukan, dapat diketahui bahwa perhatian orang tua jenis spontan berpengaruh positif terhadap hasil belajar matematika dimana semakin baik perhatian orang tua jenis spontan yang diberikan oleh orang tua, maka akan semakin tinggi pula hasil belajar matematika siswa. Hal tersebut diperkuat dengan pendapat Sandy, Suryadi \& Nasrullah (2017) perhatian dari orang tua sangatlah dibutuhkan oleh anak atau siswa karena perhatian orang tua dapat menjadi pendorong yang kuat untuk anak giat belajar dan mencapai hasil belajar yang baik. Jenis perhatian orang tua tidak hanya disengaja tetapi juga jenis perhatian spontan. Menurut Rini, Dewi \& Supangat (2020) perhatian orang tua bukan hanya memberikan kasih sayang, tetapi juga memberikan fasilitas yang nyaman kepada anak untuk mendukung kesuksesan anak dalam pendidikannya.

Berdasarkan pembahasan di atas tentang pengaruh jenis perhatian disengaja dan spontan dapat disimpulkan bahwa kedua jenis perhatian tersebut berpengaruh positif terhadap hasil belajar matematika. Hal tersebut diperkuat dari penelitian Anwar (2020) yang menyebutkan bahwa ada pengaruh positif dan signifikan perhatian orang tua terhadap hasil belajar matematika dan mempunyai kontribusi sebesar 39,7\%. Kemudian pada penelitian Mahmudi, Sulianto \& Listyarini (2020) didapatkan data bahwa sebagian 
besar anak yang mendapat hasil belajar tinggi disebabkan oleh perhatian orang tua yang sangat cukup, kemudian anak yang mendapat hasil belajar rendah disebabkan perhatian orangtua yang kurang.

Berdasarkan uji korelasi yang telah dilakukan menunjukkan bahwa nilai signifikansi penelitian ini sebesar $0,000<0,05$ yang berarti bahwa Ho ditolak, sehingga dapat disimpulkan bahwa ada korelasi antara perhatian orang tua dan hasil belajar matematika siswa kelas IV SDN se-Kecamatan Kutowinangun. Hasil analisis korelasi jenis perhatian orang tua disengaja dan hasil belajar matematika didapatkan $r$ hitung sebesar 0,754 dengan $r$ tabel sebesar 0,122 . Oleh karena itu, nilai $r$ hitung $(0,754)>r$ tabel $(0,122)$ artinya terdapat hubungan positif antara perhatian orang tua disengaja dan hasil belajar matematika dengan koefisien korelasi tersebut berada pada tingkat hubungan sangat kuat. Sedangkan hasil analisis korelasi perhatian orang tua spontan dan hasil belajar matematika didapatkan $r$ hitung sebesar 0,564 dengan $r$ tabel sebesar 0,122 . Oleh karena itu, nilai $r$ hitung $(0,564)>r$ tabel $(0,122)$ artinya terdapat hubungan antara perhatian orang tua spontan dan hasil belajar matematika dengan koefisien korelasi tersebut berada pada tingkat hubungan kuat. Hal tersebut memperkuat penelitian Sihombing, Sipayung \& Tanjung (2020) yang menyatakan bahwa korelasi perhatian orang tua dengan hasil belajar matematika siswa kelas IV SD memiliki nilai rxy 0,732 yang terletak pada rentang nilai $r$ 0,600 - 0,800 maka dapat disimpulkan tingkat hubungan antara variabel perhatian orang tua dengan hasil belajar matematika memiliki hubungan yang tinggi.

Berdasarkan hasil perhitungan, diperoleh besarnya sumbangan efektif perhatian orang tua disengaja dan hasil belajar matematika sebesar $55,5 \%$, artinya perhatian orang tua disengaja dapat berperan dalam meningkatkan hasil belajar matematika sebesar $55,5 \%$ dan $44,5 \%$ dipengaruhi oleh faktor lain. Selanjutnya, sumbangan efektif pada perhatian orang tua spontan dan hasil belajar matematika didapatkan hasil sebesar $31,8 \%$, artinya perhatian orang tua spontan dapat berperan dalam meningkatkan hasil belajar matematika sebesar $31,8 \%$ dan $68,2 \%$ dipengaruhi oleh faktor yang lain. Faktor lain yang dapat memengaruhi hasil belajar matematika yaitu pola asuh, kelekatan atau keakraban antara sesama anggota keluarga, latar belakang budaya, dan keadaan ekonomi keluarga.

\section{SIMPULAN}

Berdasarkan hasil penelitian dan pembahasan dapat ditarik kesimpulan sebagai berikut: (1) Jenis perhatian orang tua disengaja berpengaruh terhadap hasil belajar matematika siswa kelas IV SDN se-Kecamatan Kutowinangun dengan besar pengaruh $55,5 \%$. Jenis perhatian disengaja berpengaruh terhadap hasil belajar matematika dimana semakin baik perhatian orang tua jenis disengaja yang diberikan, maka akan semakin tinggi pula hasil belajar matematika siswa kelas IV. (2) Jenis perhatian orang tua spontan berpengaruh terhadap hasil belajar matematika siswa kelas IV SDN seKecamatan Kutowinangun dengan besar pengaruh 31,8\%. Jenis perhatian spontan berpengaruh terhadap hasil belajar matematika dimana semakin baik perhatian orang tua jenis spontan yang diberikan, maka akan semakin tinggi pula hasil belajar matematika siswa kelas IV.

Implikasi pada penelitian ini yaitu perhatian orang tua secara sengaja dan spontan memberikan dampak yang baik bagi anak seperti meningkatkan semangat dan motivasi belajar bagi anak. Perhatian orang tua sangatlah dibutuhkan oleh anak karena dapat menjadi pendorong yang kuat agar anak giat belajar dan mencapai hasil belajar yang baik. Oleh karena itu, penelitian ini direkomendasikan bagi guru agar menjalin kerja sama yang baik dengan orang tua siswa sehingga siswa bisa mendapatkan perhatian dalam kegiatan belajarnya, tidak hanya di sekolah namun juga di rumah. 


\section{DAFTAR PUSTAKA}

Adiani, N.P., dan Kristiantari, M. G. R. (2020). The Positive Impact of Auditory Intellectually Repetition Learning Model Assisted by Domino Card on Mathematics Learning Outcomes. International Journal of Elementary Education, 4(3), 270-280.

Anwar, A.S. (2020). Pengaruh Kedisiplinan, Perhatian Orang Tua dan Minat terhadap Hasil Belajar Matematika. Maju Jurnal Ilmiah Pendidikan Matematika, 7(1).

Kurniawan, D., dan Dhoriva, U.W. (2014). Pengaruh Perhatian Orangtua, Motivasi Belajar, Dan Lingkungan Sosial Terhadap Prestasi Belajar Matematika Siswa SMP. Jurnal Riset Pendidikan Matematika, Volume 1 - Nomor 2, November 2014.

Mahmudi, A., Sulianto, J., \& Listyarini, I. (2020). Hubungan Perhatian Orang Tua terhadap Hasil Belajar Kognitif Siswa. Jurnal Pedagogi dan Pembelajaran, 3(1), 122-129.

Nahdi, D.S. (2019). Keterampilan Matematika di Abad 2. JURNAL CAKRAWALA PENDAS. Media Publikasi pada Bidang Pendidikan Dasar p-ISSN: 2442-7470 / eISSN: 2579-4442. Volume 5 Nomor 2 Edisi Juli 201.

Nur, M.A. (2016). Pengaruh Perhatian Orang Tua, Konsep Diri, Persepsi Tentang Matematika Terhadap Hasil Belajar Matematika Melalui Motivasi Belajar Siswa Kelas VIII SMP Negeri di Kecamatan Ujung Loe Kabupaten Bulukumba. Jurnal Matematika dan Pembelajarannya 2016 Volume 2, No. 2. ISSN 2303-0992.

Priyatno, D. (2012). Belajar Cepat Olah Data Statistik dengan SPSS. Yogyakarta: Andi Yogyakarta.

Rini, E.S. (2015). Pengaruh Perhatian Orang Tua dan Kedisiplinan Siswa Terhadap Prestasi Belajar Mata Pelajaran IPS. Jurnal Penelitian dan Pendidikan IPS (JPPI) Volume 9 No 2 (2015) 1131-1149.

Rini, I.S., Dewi, S.E., \& Supangat. (2020). Pengaruh Perhatian Orang Tua dalam Kegiatan Belajar terhadap Prestasi Belajar Siswa Di SD Negeri Nusa Tunggal Kecamatan Belitang III. Jemari: Jurnal Edukasi Madrasah Ibtidaiyah, Vol. 2 No. 2.

Safitri, S. dan Nurhayati, N. (2018). Studi Pustaka: Pengaruh Perhatian Orang Tua terhadap Prestasi Belajar Siswa di Sekolah. Journal of Educational Review and Research, 1(2), 64-67.

Sandy, L.L., Suryadi \& Nasrullah, A. (2017). Pengaruh Perhatian Orang Tua dan Motivasi Belajar terhadap Peningkatan Prestasi Belajar Siswa. Jurnal Penelitian Bimbingan dan Konseling, 2(1).

Sihombing, S., Sipayung, R., \& Tanjung, D.S. (2020). Pengaruh Perhatian Orang Tua terhadap Hasil Belajar Siswa Pada Mata Pelajaran Matematika di Kelas IV SD Negeri 097350 Parbutaran Simalungun. School Education Journal Volume 10, No. 4 Desember 2020.

Theresya, J., Latifah, M., \& Hernawati, N. (2018). The Effect of Parenting Style, SelfEfficacy, and Self Regulated Learning on Adolescents' Academic Achievement. Journal of Child Development Studies E-ISSN : 2460-231 2018, Vol. 03, No. 01, page 28-43.

Wahyudi. (2015). Paduan Pembelajaran Matematika Sekolah Dasar. Surakarta: UNS PRESS. 